\title{
PENERAPAN PENDEKATAN KONSTRUKTIVISME UNTUK MENINGKATKAN KEMAMPUAN PENALARAN MATEMATIS PESERTA DIDIK PADA MATERI STATISTIKA KELAS 12 SMA NEGERI 4 BOJONEGORO
}

\author{
Nurul Ilmiyah ${ }^{1}$, Suyoto ${ }^{2}$ \\ SMA Negeri 4 Bojonegoro ${ }^{1}$ \\ hafidzhkarya@gmail.com \\ Universitas Muhammadiyah Gresik ${ }^{2}$
}

\begin{abstract}
Abstrak
Salah satu ciri matematika adalah menekankan pada proses deduktif aksiomatik yang memerlukan penalaran logis. Penalaran masuk dalam kompetensi dasar yang harus dikuasai siswa, sehingga diharapkan siswa dapat menganalisis suatu permasalahan sebelum mengambil suatu keputusan sebagai bekal untuk menghadapi tantangan perkembangan dan perubahan. Fakta menunjukkan bahwa kemampuan siswa dalam bernalar belum diperhatikan secara mendalam. Untuk itu diperlukan pembelajaran yang didesain menurut pandangan konstruktivisme karena menurut pandangan tersebut pembelajaran bertujuan untuk membantu peserta didik untuk membangun konsep-konsep/ prinsip-prinsp matematika dengan kemampuannya sendiri melalui asimilasi dan akomodasi.

Penelitian ini merupakan Penelitian Tindakan Kelas (PTK) dengan tujuan meningkatkan kemampuan penalaran matematika melalui pendekatan konstruktivisme. Subjek pada penelitian ini adalah peserta didik kelas XII IPA 2 SMA Negeri 4 Bojonegoro sebanyak 33 orang. Prosesur dalam penelitian ini meliputi perencanaan, pelaksanaan, observasi, dan refleksi. Perangkat pembelajaran dalam penelitian ini adalah Rencana Pelaksanaan Pembelajaran (RPP), bahan ajar, dan Lembar Kerja Peserta Didik (LKPD) sedangkan instumen penelitian yang digunakan adalah Tes Kemampuan Penalaran (TKP).

Dari hasil analisis data, dapat disimpulkan bahwa kemampuan penalaran matematis peserta didik kelas XII IPA 2 telah memenuhi indicator keberhasilan penelitian setelah siklus kedua, yaitu sebanyak 67\% (24 peserta didik) memenuhi kriteria baik dalam bernalar. Keterlaksanaan pembelajaran tergolong baik pada siklus kedua yaitu seluruh pembelajaran terlaksana dengan prosentase $88,5 \%$.
\end{abstract}

Kata kunci: kemampuan penalaran matematis, pendekatan konstruktivisme

\footnotetext{
Abstrack

One feature of mathematics is the emphasis on axiomatic deductive processes that require logical reasoning. Reasoning is included in the basic competencies that students must master, so students are expected to be able to analyze a problem before making a decision as a provision to face the challenges of development and change. The fact shows that the ability of students in reasoni DIDAKTIKA Volume 27 No 1 September 2020 reason, learning is designed according to

to that view learning aims to help students to develop mathematical concepts / principles with their own abilities through assimilation and accommodation.

This research is a Classroom Action Research (CAR) with the aim of improving the ability of mathematical reasoning through a constructivism approach. The subjects in this study were students of class XII IPA 2 of SMA Negeri 4 Bojonegoro totaling 33
} 
people. Processors in this study include planning, implementing, observing, and reflecting. The learning tool in this study is the Learning Implementation Plan (RPP), teaching materials, and Student Worksheets (LKPD) while the research instrument used is Reasoning Ability Test (TKP).

From the results of data analysis, it can be concluded that the mathematical reasoning ability of students in class XII IPA 2 has met the indicators of research success after the second cycle, as many as 67\% (24 students) meet the criteria of good reasoning. The implementation of learning is classified as good in the second cycle, namely all learning is carried out with a percentage of $88.5 \%$.

Keywords: mathematical reasoning ability, constructivism approach.

\section{PENDAHULUAN}

Penyelenggaraan

matematika

sekolah di Indonesia saat ini diatur dalam Kurikulum 2013 (Kemendikbud, 2013) yang dengan tujuan pembelajaran matematika menekankan pada dimensi pedagogik modern, yaitu menggunakan pendekatan scientific (ilmiah) melalui kegiatan mengamati, menanya, mencoba, menalar, menyaji dan mencipta. NCTM (2000) menjelaskan bahwa dalam belajar matematika siswa dituntut untuk memiliki kemampuan: (1) komunikasi matematis, (2) pemalaran matematis, (3) pemecahan masalah matematis, (4) koneksi matematis, dan (5) representasi matematis. Berdasarkan penyataan tersebut, terlihat bahwa kemampuan penalaran adalah salah satu kemampuan yang harus dimiliki peserta didik sebagai standar yang harus dikembangkan terutama pada pembelajaran matematika.

\section{Matematika} merupakan pengetahuan tentang penalaran logis dan pengetahuan tentang struktur yang logis
(Soedjadi, 2000: 11). Berdasarkan pendapat tersebut, wajar jika penalaran masuk dalam kompetensi dasar yang harus dikuasai siswa, sehingga diharapkan siswa dapat menganalisis suatu permasalahan sebelum mengambil suatu keputusan sebagai bekal untuk menghadapi tantangan perkembangan dan perubahan. Penalaran matematika adalah fondasi untuk mendapatkan atau mengkonstruk pengetahuan matematika. Demikian guru di sekolah dasar hingga menengah harus mengembangkan kemampuan penalaran peserta didik dalam pembelajaran matematika.

Matematika dan penalaran merupakan dua hal yang tidak dapat dipisahkan. Materi matematika dapat dipahami melalui penalaran, sebaliknya penalaran dapat dilatih dan dikembangkan melalui belajar matematika. Berdasarkan pendapat tersebut, wajar jika penalaran masuk dalam kompetensi dasar yang harus dikuasai siswa, sehingga diharapkan siswa dapat menganalisis suatu permasalahan 
sebelum mengambil suatu keputusan sebagai bekal untuk menghadapi tantangan perkembangan dan perubahan. Demikian, guru di sekolah dasar hingga menengah harus mengembangkan kemampuan penalaran peserta didik dalam pembelajaran matematika.

Matematika dan penalaran merupakan dua hal yang tidak dapat dipisahkan. Materi matematika dapat dipahami melalui penalaran, sebaliknya penalaran dapat dilatih dan dikembangkan melalui belajar matematika. Dengan belajar matematika keterampilan berpikir peserta didik akan meningkat karenaa pola piker yang dikembangkan matematika membutuhkan pemikiran kritis, sistematik, logis dan kreatif sehingga peserta didik akan mampu menarik kesimpulan dari berbagai fakta atau data yang mereka dapatkan.

Beberapa penelitian menunjukkan bahwa kurangnya kemampuan peserta didik dalam bernalar, misalnya salah satu penelitian dari Priatna (2003) yang mengemukakan bahwa kualitas kemampuan penalaran (analogi dan generalisasi) rendah karena skor hanya $49 \%$ dari skor ideal. Berdasarkan permasalahan tersebut, guru seharusnya mengupayakan pembelajaran yang dapat memberikan peluang dan mendorong peserta didik untuk melatihkan kemampuan penalaran melalui model- model belajar yang inovatif, bukan hanya mementingkan pada nilai yang diperoleh peserta didik. Hal ini menjadi tantangan baru bagi guru untuk meningkatkan kemampuan penalaran peserta didik.

Selain itu berdasarkan pengalaman peneliti sebagai guru SMA Negeri 4 Bojonegoro serta wawancara dengan teman guru bahwa pada materi statistika, rata-rata nilai peserta didik selalu tidak mencapai nilai Kriteria Ketuntasan Minimal (KKM). Hal ini dikarenakan peserta didik mengalami kesulitan dalam menyelesaikan masalah yang melibatkan materi statistika. Selama ini proses pembelajaran matematika yang dilakukan di SMA Negeri 4 Bojonegoro masih menggunakan pendekatan konvensional, sehingga kurang melibatkan kemampuan peserta didik dalam berdiskusi untuk menyusun ide-ide matematis yang terkait dengan statistika. Padahal pembelajaran yang diduga dapat menumbuhkan kemampuan bernalar peserta didik adalah pembelajaran yang didesain menurut pandangan konstruktivisme.

Menurut Piaget (dalam Rosita 2014) pembentukan pengetahuan menurut teori konstruktivisme adalah memandang subyek aktif menciptakan struktur-struktur kognitif dalam interaksinya dengan lingkungan. Dengan demikian, menurut teori konstruktivisme pengetahuan yang ditransformasikan bukan sesuatu yang 
berdiri sendiri tetapi diciptakan dan dirumuskan kembali (created and recreated). Sehingga dapat dikatakan bahwa pendekatan konstruktivisme adalah suatu pandangan yang didasarkan pada aktivitas peserta didik untuk menciptakan, menginterpretasikan, dan mengorganisasikan pengetahuan dengan jalan individual. Tujuan penggunaan pendekatan konstruktivisme adalah untuk membantu meningkatkan pemahaman peserta didik terhadap isi atau materi pembelajaran.

Dalam pembelajaran matematika dengan pendektan konstruktivisme, peserta didik mengkonstruk sendiri pengetahuan di dalam benaknya baik secara individu maupun kelompok. Menurut Santyasa (dalam Rosita, 2014) tujuan utama belajar menurut pandangan konstruktivisme didasarkan pada tiga fokus belajar, yaitu proses, transfer belajar, dan bagaimana belajar. Proses mengandung makna bahwa belajar adalah proses pemaknaan informasi baru. Transfer belajar berarti bahwa belajar bermakna harus diyakini memiliki nilai yang lebih baik dibanding dengan belajar menghafal sehingga pemahaman akan lebih baik hafalan. Sebagai bukti pehamanan mendalam adalah kemampuan mentansfrer apa yang dipelajari ke dalam situasi yang baru. Sedangkan fokus bagaimana belajar memiliki nilai yang lebih penting dibandingkan dengan apa yang dipelajari.

Slavin (2000) mengemukakan bahwa: students must construct knowledge in their own mind. Pendapat serupa juga dikemukakan oleh Glaserfeld (dalam Yevdokimov, 1999) yaitu learning is a process of construction in which the students themselves have to be the primary actors. Pendapat tersebut menegaskan bahwa dalam proses pembelajaran, peserta didiklah yang membangun pengetahuannya sendiri. Guru berperan sebagai fasilitator dan menyediakan pembelajaran. Penekanan tentang belajar mengajar lebih berfokus pada suksesnya peserta didik dalam mengorganisasi penglamannya. Guru dapat memberikan kemudahan untuk proses ini dengan memberi kesempatan peserta didik untuk menemukan atau menerapkan ide-ide mereka sendiri dengan cara memberi anak tangga yang membawa peserta didik ke pemahaman yang lebih tinggi dengan catatan peserta didik sendiri yang memanjat anak tangga tersebut.

Berdasarkan pemaparan di atas, peneliti tertarik untuk melakukan Penelitian Tindakan Kelas untuk meningkatkan kemampuan penalaran peserta didik melalui pendekatan konstruktivisme pada materi statistika kelas XII SMA Negeri 4 Bojonegoro tahun pelajaran 2019/2020. 


\section{METODE}

Jenis penelitian ini adalah Penelitian Tindakan Kelas (PTK). PTK dilakukan oleh guru di dalam kelasnya sendiri melalaui refleksi diri dengan tujuan untuk memperbaiki kinerjanya sebagai guru sehingga kemampuan penalaran peserta didik menjadi meningkat. Penelitian ini dilaksanakan di SMA Negeri
4 Bojonegoro pada peserta didik kelas XII IPA 2. Jumlah peserta didik sebanyak 36 orang, terdiri dari 12 peserta didik laki-laki dan 24 perempuan.

Berikut adalah desain Penelitian Tindakan Kelas (Classroom action research) yang ada pada Gambar 1 dibawah ini:

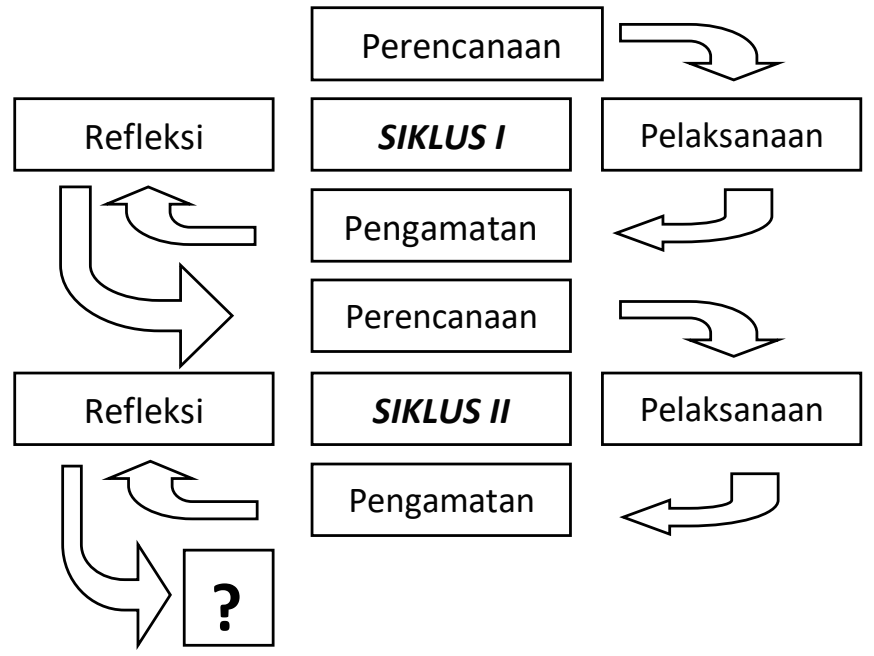

Gambar 1. Siklus PTK (Sumber: Arikunto, dkk, 2012:16) 
Pada tahap perencanaan, meliputi: (a) menetapkan Kompetensi Dasar (KD) dan Indikator Pencapaian Kompetensi (IPK), (b) membuat Rencana Pelaksanaan Pembelajaran (RPP) yang akan diterapkan dalam proses belajar mengajar, (c) menentukan skenario pembelajaran, (d) mempersiapkan sumber, bahan dan alat bantu yang dibutuhkan, (e) menyusun Lembar Kegiatan Peserta Didik (LKPD), dan (f) menyusun soal Tes Kemampuan Penalaran (TKP).

Pada tahap pelaksanaan, meliputi seluruh proses kegiatan belajar mengajar Matematika sub materi ukuran pemusatan data melalui Model Kooperatif pendekatan konstruktivis. Penerapan tindakan siklus ini dilakukan sebanyak 3 kali pertemuan.

Tahap pengamatan, dilakukan pada saat proses pembelajaran berlangsung yakni meliputi aktivitas peserta didik, dan kemampuan penalaran matematis peserta didik.

Tahap refleksi, meliputi kegiatan analisis hasil pembelajaran dan sekaligus menyusun rencana perbaikan pada siklus berikutnya.

Perangkat pembelajaran yang digunakan pada penelitian ini adalah Rencana Pelaksanaan Pembelajaran (RPP), Lembar Kerja Peserta Didik (LKPD), dan Modul Pembelajaran. Sedangkan untuk instrumen yang akan digunakan adalah tes untuk kemampuan penalaran dan lembar observasi pada pembelajaran dengan pendekatan konstruktivis.

Data-data yang diperoleh dalam penelitian akan dianalisis dengan berbagai teknik. Data hasil Tes Kemampuan Penalaran dan Komunikasi (TKPK) secara tulis akan dianalisis berdasarkan kriteria sebagai berikut yang disajikan dalam bentuk tabel di bawah ini:

Tabel 1. Kriteria kemampuan penalaran dan komunikasi

\begin{tabular}{|c|l|}
\hline Skor & \multicolumn{1}{|c|}{ Kriteria } \\
\hline $4-6$ & tidak baik \\
\hline $7-9$ & cukup baik \\
\hline $10-13$ & baik \\
\hline $14-16$ & sangat baik \\
\hline Selain itu keterlaksanaan
\end{tabular}

pembelajaran dengan pendekatan konstruktif juga perlu dianalisis. Berikut ini adalah konveksi nilai keterlaksanaan pembelajaran dengan pendekatan konstruktif berupa tabel:

Tabel 2. Konveksi Nilai Keterlaksanaan Pembelajaran dengan Pendekatan Konstruktif

\begin{tabular}{|c|c|}
\hline Rata-rata nilai & Kriteria \\
\hline $1,00 \leq R N K<1,75$ & Tidak baik \\
\hline $1,75 \leq R N K<2,50$ & Kurang baik \\
\hline $2,50 \leq R N K<3,25$ & Baik \\
\hline $3,25 \leq R N K<4,00$ & Sangat baik \\
\hline
\end{tabular}

Sumber: Lince dalam Suryatika (2009:56)

Keterangan: $\mathrm{RNK}=$ Rata-rata Nilai Kategori 
Kriteria keberhasilan penelitian ini dilihat dari hasil tes kemampuan penalaran matematis peserta didik secara keseluruhan dengan aturan sebagai berikut:

$$
\text { Jika } \geq 65 \% \text { dari PDB : kemampuan }
$$

penalaran dapat dikatakan baik

Jika $<65 \%$ dari PDB : kemampuan penalaran dapat dikatakan tidak baik.

PDB $=$ Jumlah keseluruhan peserta didik yang termasuk dalam kriteria sangat baik atau baik dalam bernalar

Sedangkan pelaksanaan pembelajaran matematika dengan pendekatan konstruktivis dalam penelitian ini dikatakan berhasil jika memenuhi kriteria sebagai berikut:

$$
\begin{aligned}
& \text { Jika } \geq 85 \% \text { dari PMBL : berhasil } \\
& \text { Jika }<85 \% \text { dari PMBL : tidak }
\end{aligned}
$$
berhasil

Keterangan: PMBL $=$ Jumlah keseluruhan pembelajaran terlaksana sangat baik atau baik.

\section{HASIL DAN PEMBAHASAN}

\section{Hasil belajar siswa}

Berikut ini adalah hasil kemampuan penalaran matematis yang diperoleh dari siklus pertama dan disajikan pada Diagram 1:

\section{Hasil Kemampuan Penalaran Matematis pada Siklus Pertama}

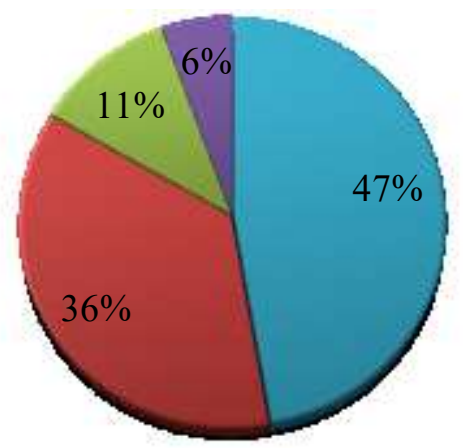

$\square$ tidak baik

曰cukup baik

$\square$ baik

$\square$ sangat baik

Diagram 1. Hasil Kemampuan Penalaran Matematis Peserta Didik pada Siklus Pertama

Berdasarkan diagram di atas dapat diketahui bahwa sebanyak 17 peserta didik (47\%) memenuhi kriteria tidak baik dalam bernalar, 13 peserta didik (36\%) memenuhi kriteria cukup baik dalam bernalar, 4 peserta didik (11\%) memenuhi kriteria baik dalam bernalar, dan 2 peserta didik (6\%) memenuhi kriteria sangat baik dalam bernalar.

Hasil di atas menunjukkan bahwa hanya 6 peserta didik ( $17 \%$ ) yang memenuhi kriteria baik atau sangat baik. 
Sehingga dapat dikatakan bahwa siklus pertama belum memenuhi kriteria kemampuan penalaran peserta didik kelas yang telah ditentukan karena $<65 \%$ dari XII IPA 2 termasuk dalam kategori tidak baik, artinya peserta didik tidak mampu menyajikan pernyataan matematika secara lisan, tertulis, dan gambar; menarik kesimpulan, menyusun bukti, memberikan alasan atau bukti beberapa solusi; memeriksa kesahihan suatu argumen; dan menemukan pola atau sifat dari gejala matematis untuk membuat generalisasi.

Hasil penilaian kemampuan keseluruhan peserta didik belum termasuk dalam kriteria sangat baik atau baik dalam bernalar. Dengan demikian, perlu diadakan pembelajaran dengan pendekatan kontruktivisme pada siklus ke dua dengan dua pertemuan.

Sedangkan di bawah ini adalah hasil kemampuan penalaran matematis yang diperoleh dari siklus kedua yang disajikan pada Diagram 2 sebagai berikut: penalaran matematis peserta didik pada

\section{Hasil Kemampuan Penalaran Matematis pada Siklus Kedua}

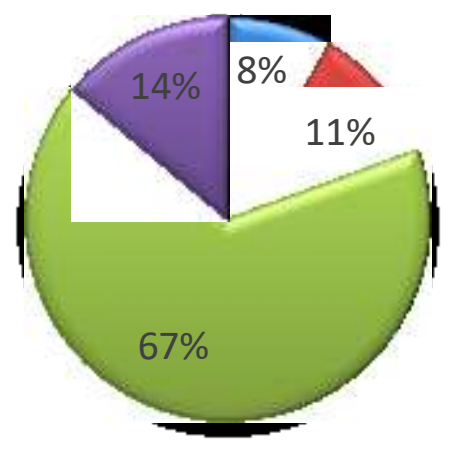

Tidak Baik

口Cukup

口Baik

$\square$ Sangat Baik

Diagram 2. Hasil kemampuan Penalaran Matematis Peserta didik pada siklus kedua

Berdasarkan diagram di atas dapat diketahui bahwa sebanyak 3 peserta didik (8\%) memenuhi kriteria tidak baik dalam bernalar, 4 peserta didik (11\%) memenuhi kriteria cukup baik dalam bernalar, 24 peserta didik (67\%) memenuhi kriteria baik dalam bernalar, dan 5 peserta didik (14\%) memenuhi kriteria sangat baik dalam bernalar.
Hasil di atas menunjukkan bahwa hanya 24 peserta didik (67\%) yang memenuhi kriteria baik dalam bernalar. Sehingga dapat dikatakan bahwa kemampuan penalaran dan komunikasi peserta didik kelas XII IPA 2 termasuk dalam kategori baik, artinya peserta didik mampu menyajikan pernyataan matematika secara lisan, tertulis, dan 
gambar; menarik kesimpulan, menyusun bukti, memberikan alasan atau bukti beberapa solusi; memeriksa kesahihan suatu argumen; dan menemukan pola atau sifat dari gejala matematis untuk membuat generalisasi.

Hasil penilaian kemampuan penalaran matematis peserta didik pada siklus kedua telah memenuhi kriteria yang telah ditentukan karena $>65 \%$ dari keseluruhan peserta didik termasuk dalam kriteria baik dalam bernalar. Dengan demikian, penelitian telah memenuhi kriteria berhasil dalam 2 siklus sehingga tidak perlu dilaksanakan pembelajaran pada siklus berikutnya.

Selain itu, berikut Tabel 1 yang merupakan tabel peningkatan kemampuan penalaran komunikasi matematis peserta didik dan keterlaksanaan pembelajaran dengan pendekatan konstruktivis yang dilaksanakan dalam dua siklus:

Tabel 3. Data Pengingkatan Hasil Penelitian

\begin{tabular}{|c|c|c|c|}
\hline \multicolumn{2}{|c|}{$\begin{array}{l}\text { Kemampuan penalaran matematis } \\
\text { peserta didik }\end{array}$} & \multicolumn{2}{|c|}{$\begin{array}{l}\text { Keterlaksanaan pembelajaran dengan } \\
\text { pendekatan konstruktivis }\end{array}$} \\
\hline Siklus Pertama & Siklus Kedua & Siklus Pertama & Siklus Kedua \\
\hline $\begin{array}{ll}\text { - } & 47 \% \text { (tidak } \\
\text { baik dalam } \\
\text { bernalar) } \\
\text { - } 36 \% \text { (cukup } \\
\text { dalam } \\
\text { bernalar) } \\
\text { - } 11 \% \text { (baik } \\
\text { dalam } \\
\text { bernalar) } \\
\text { 6\% (sangat } \\
\text { baik dalam } \\
\text { bernalar) }\end{array}$ & $\begin{array}{ll}\text { - } & 8 \% \text { (tidak } \\
\text { baik dalam } \\
\text { bernalar) } \\
11 \% \text { (cukup } \\
\text { dalam } \\
\text { bernalar) } \\
\text { - } 67 \% \text { (baik } \\
\text { dalam } \\
\text { bernalar) } \\
\text { - } 14 \% \text { (sangat } \\
\text { baik dalam } \\
\text { bernalar) }\end{array}$ & $\begin{array}{l}\text { Seluruh } \\
\text { pembelajaran } \\
\text { terlaksana } \\
\text { dengan } \\
\text { prosentase } \\
84,6 \%\end{array}$ & $\begin{array}{l}\text { Seluruh pembelajaran } \\
\text { terlaksana dengan } \\
\text { prosentase } 88,5 \%\end{array}$ \\
\hline
\end{tabular}

Berdasarkan tabel di atas, terlihat bahwa terjadi peningkatan data pada kemampuan penalaran matematis peserta didik dan keterlaksanakan pembelajaran dengan pendekatan konstruktivis. Pada siklus pertama, kemampuan penalaran matematis peserta didik pada sub materi ukuran peserta didik dalam kategori tidak baik dalam bernalar, karena hanya 11\% dan $6 \%$ peserta didik mampu mencapai kriteria baik dan sangat baik dalam bernalar, sehingga belum memenuhi kriteria keberhasilan penelitian. Sedangkan pada pertemuan kedua, sebanyak 67\% (24 peserta didik) tergolong baik dalam bernalar, sehingga telah memenuhi kriteria 
keberhasilan penelitian. Dengan demikian, penelitian dilaksanakan dalam dua siklus.

Dalam hal keterlaksanaan pembelajaran juga terjadi peningkatan. Pada siklus pertama, seluruh pembelajaran terlaksana dengan prosentase $84,6 \%$. Oleh karena itu, dilakukan refleksi dan perbaikan dalam pembelajaran, misalnya dalam hal pemberian motivasi kepada peserta didik oleh guru. Pada siklus kedua, guru memberikan motivasi yang lebih baik kepada peserta didik, sehingga terjadi peningkatan nilai dalam aspek pemberian motivasi. Hal ini menyebabkan seluruh pembelajaran pada siklus kedua terlaksana dengan prosentasi $88,5 \%$.

\section{PENUTUP}

\section{Simpulan}

Berdasarkan hasil penelitian tentang peningkatan kemampuan penalaran matematis peserta didik melalui pembelajaran dengan pendekatan konstruktivis diperoleh simpulan sebagai berikut.

1. Hasil tes kemampuan penalaran matematis peserta didik pada sub materi pokok ukuran pemusatan data menunjukkan bahwa kemampuan penalaran peserta didik kelas XII IPA 2 termasuk dalam kategori tidak baik pada siklus pertama. Artinya siswa tidak mampu menyajikan

pernyataan

matematika secara lisan, tertulis, dan gambar; menarik kesimpulan, menyusun bukti, memberikan alasan atau bukti beberapa solusi; memeriksa kesahihan suatu argumen; dan menemukan pola atau sifat dari gejala matematis untuk membuat generalisasi. Hal ini ditunjukkan bahwa sebanyak 6 siswa (17\%) memenuhi kriteria baik atau sangat baik. Sedangkan, pada siklus kedua, kemampuan penalaran matematis peserta didik telah memenuhi kriteria baik sesuai kriteria keberhasilan yang ditentukan, yaitu sebanyak 24 peserta didik (67\%) tergolong baik dalam bernalar.

2. Pembelajaran dengan pendekatan konstruktivis pada sub materi ukuran pemusatan data terlaksana dengan baik dengan rata-rata nilai kategori sebesar 3,11 pada pertemuan pertama. Hal ini berarti pembelajaran terlaksana dengan prosentase sebesar $84,6 \%$. Prosentase ini belum memenuhi kriteria keberhasilan yang telah ditetapkan dalam penelitian ini. Pada siklus kedua, telah terjadi 


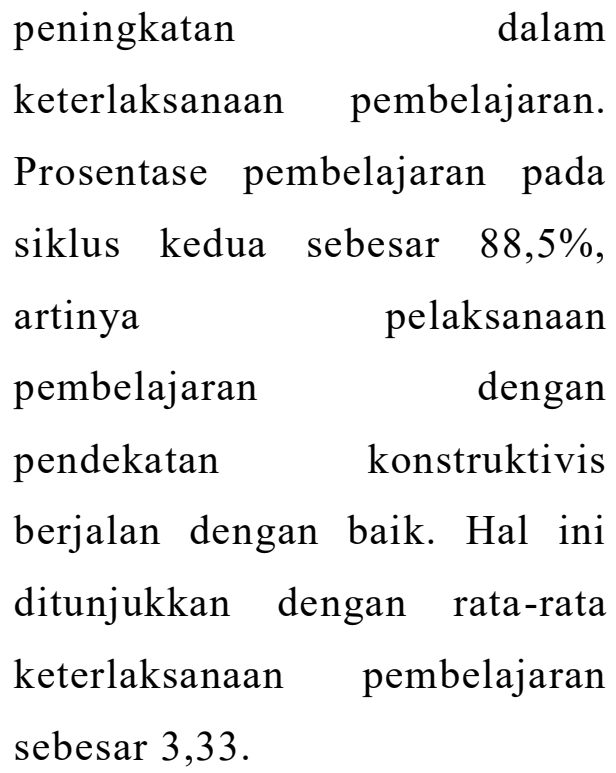

\section{Saran}

Berdasarkan hasil penelitian dan kesimpulan, beberapa saran dalam penelitian ini adalah sebagai berikut:

1. Soal yang dibuat untuk mengukur kemampuan penalaran matematis peserta didik sebaiknya di buat dengan karakteristik yang tidak sama untuk setiap butir soal.

2. Bagi peneliti lain yang akan melakukan penelitian dengan judul yang sama, hendaknya melakukan penilaian kemampuan penalaran matematis pembelajaran saat diskusi dalam pembelajaran dengan pendekatan konstruktivis.

\section{DAFTAR PUSTAKA}

NCTM. 2000. Principles and Standards for School Mathematics. USA: NCTM.

Priatna, N. 2003. Kemampuan Penalaran Matematika Siswa Kelas 3 Sekolah Lanjutan Tingkat Pertama Negeri Di Kota Bandung. Disertasi pada PPs UPI. Bandung : tidak dipublikasikan.

Rosita, Cita Dwi. 2014. Kemampuan Penalaran dan Komunikasi Matematis: Apa, Mengapa, dan Bagaimana ditingkatkan pada Mahasiswa. Jurnal Euclid Vol 1 No 1, pp 1 - 59.

Yevdokimov. 1999. About a Constructivist Approach for Stimulating Students' Thinking to Produce Conjecture and Their Proving in Active Learning of Geometry. (online) http://eprints.usq.edu.au/33 $\underline{\text { 52/1/1-Yevdokimov }}$ CERME4.pdf 